\title{
ANALISIS KADAR LOGAM MERKURI (Hg) DAN (pH) AIR SUNGAI KUANTAN TERDAMPAK PENAMBANGAN EMAS TANPA IZIN (PETI)
}

\author{
Putri Ade Rahma Yulis \\ Universitas Islam Riau \\ Email: putriaderahmayulis@edu.uir.ac.id
}

\begin{abstract}
Abstrak: Semakin maraknya aktivitas Penambangan Emas Tanpa Izin (PETI) di Kabupaten Kuantan Singingi mengakibatkan munculnya beragam permasalahan, terutama pencemaran air Sungai Kuantan yag menjadi lokasi aktivitas penambangan. Oleh karena itu pada penelitian kali ini dilakukan analisis kualitas air Sungai Kuantan khususnya di Desa Bandar Alai Kari Kecamatan Kuantan Tengah Kabupaten Kuantan Singingi yang meliputi derajat keasaman $(\mathrm{pH})$ dan kadar $\mathrm{Hg}$ atau logam merkuri yang kita ketahui sangat berbahaya bagi tubuh yang merupakan hasil limbah dari pengolahan emas secara amalgamasi. Metode yang digunakan dalam penelitian ini yaitu metode survei dengan penentuan titik sampling secara purposive berdasarkan lokasi maraknya aktivitas PETI. Pengambilan sampel dilakukan pada 3 titik mulai dari daerah hulu, tengah dan hilir. Dari hasil penelitian didapatkan nilai pH berkisar diatas pH 6 antara 6,46 - 6,50, nilai ini masih memenuhi angka baku mutu yang ditetapkan, kemudian untuk kadar logam berat merkuri 12,67 ppb - 13,60 ppb $(\mu \mathrm{g} / \mathrm{L})$ dan kadar merkuri ini sudah melampaui angka baku mutu yang diizinkan.
\end{abstract}

Kata Kunci: Limbah PETI, analisis kadar air, logam berat

\section{PENDAHULUAN}

Saat ini pencemaran air terutama di perairan terbuka (sungai) merupakan permasalahan yang serius. Kabupaten Kuantan Singingi (Kuansing) merupakan kawasan berkembang (growth city) yang ditandai dengan berbagai permasalahan yang kompleks. Kompleksitas permasalahan yang multidimensi tersebut dihadapi oleh sektor pertambangannya. Hal ini ditandai dengan semakin maraknya aktivitas Penambangan Emas Tanpa Izin (PETI) di Kabupaten Kuansing. Sungai di Kabupaten Kuansing terdiri dari dua sungai utama, yaitu Sungai Kuantan (DAS Indragiri) dan Sungai Singingi (DAS Kampar). Sungai inilah yang dimanfaatkan oleh masyarakat dalam kehidupan sehari - hari. Sungai ini berfungsi sebagai sumber air minum, MCK, pertanian, industri, perhubungan, dan pariwisata yang memberikan kostribusi besar bagi masyarakat (Tasriani dan Zulhadi, 2013).

Penambangan emas memang merupakan suatu kegiatan yang dapat meningkatkan pendapatan masyarakat, namun demikian penambangan emas juga dapat merugikan apabila dalam pelaksanaannya tanpa diikuti proses pengolahan limbah hasil pengolahan bijih emas secara baik. Menurut (Mirdat, 2013) salah satu cara pengolahan bijih emas adalah proses amalgamasi yang menggunakan merkuri $(\mathrm{Hg})$ dalam proses pengolahannya. Merkuri biasa digunakan sebagai bahan kimia pembantu yang sesuai dengan sifatnya untuk mengikat butiranbutiran emas agar mudah dalam pemisahan dengan partikel-partikel lainnya. Cara penambangan emas dan pengolahan bijih emas oleh para penambang liar ini sangat sederhana, tetapi akibat kesederhanaan dan ketidaktahuan serta ketidakpedulian mereka telah membawa akibat buruk bagi kelangsungan hidup di 
lingkungan sekitarnya yang berpotensi menyebabkan efek racun pada lingkungan perairan.

Logam berat menjadi berbahaya disebabkan sistem bioakumulasi yaitu peningkatan konsentrasi unsur kimia di dalam tubuh makhluk hidup. Logamlogam berat dapat menimbulkan efek kesehatan bagi manusia tergantung pada bagian mana logam berat tersebut terikat dalam tubuh. Daya racun yang dimiliki akan bekerja sebagai penghalang kerja enzim sehingga proses metabolisme tubuh terputus (Nuraini, 2015). Merkuri dalam bentuk logam biasanya akan menumpuk di ginjal dan sistem saraf yang akan mengganggu bila akumulasinya semakin banyak (Edward, 2008). Adapun kadar merkuri Menurut Peraturan Menteri Kesehatan maksimum di dalam air sebesar 0,001 mg/L atau sekitar $1(\mu \mathrm{g} / \mathrm{L})$. Apabila merkuri masuk ke perairan akan berikatan dengan chlor yang ada didalam air membentuk ikatan $\mathrm{HgCl}$. Dalam bentuk tersebut $\mathrm{Hg}$ akan mudah masuk ke dalam plankton dan berpindah ke biota air lainnya. Manusia dapat terakumulasi merkuri melalui konsumsi makanan yang tercemar seperti dari ikan dan kerang (Narasiang, 2015). Hg atau merkuri merupakan salah satu unsur yang paling beracun diantara logam berat yang ada dan apabila terpapar pada konsentrasi yang tinggi maka akan mengakibatkan kerusakan otak secara permanen dan kerusakan ginjal (Stancheva, 2013). Dikarenakan operasional penambangan emas biasa menggunakan air raksa atau $\mathrm{Hg}$ sebagai media pengikat emas dan biasanya akan membuang limbahnya yang masih mengandung merkuri ke perairan, maka sangat penting untuk mendeteksi seberapa besar kandungan logam merkuri yang ada di aliran sungai tersebut, selain itu juga akan diukur derajat keasaman atau $\mathrm{pH}$ pada beberapa titik dikarenakan kita ketahui bahwa nilai $\mathrm{pH}$ merupakan suatu indeks kadar ion hidrogen $\left(\mathrm{H}^{+}\right)$yang mencirikan keseimbangan asam dan basa. Nilai $\mathrm{pH}$ pada suatu perairan mempunyai pengaruh yang besar terhadap organisme perairan sehingga seringkali dijadikan petunjuk untuk menyatakan baik buruknya suatu perairan.

Berdasarkan pemaparan literatur mengenai bahaya yang dapat diakibatkan oleh logam berat khususnya merkuri dan maraknya aktivitas penambangan emas serta belum pernah dilakukannya analisis logam merkuri di daerah tersebut, maka dilakukanlah penelitian ini dengan tujuan memberikan informasi tentang kadar logam merkuri air Sungai Kuantan sehingga dapat digunakan sebagai bahan pertimbangan dalam penanganan limbah aktivitas PETI di Kabupaten Kuansing Provinsi Riau di masa yang akan datang. Hasil penelitian ini diharapkan dapat menyediakan kajian akademik tentang dampak PETI terutama kandungan logam beratnya terhadap kualitas air sungai serta dapat dijadikan sebagai rujukan dalam perkuliahan.

\section{METODOLOGI PENELITIAN}

Penelitian ini dilaksanakan di Laboratorium Universitas Islam Riau Pekanbaru serta Laboratorium Balai Riset dan Standarisasi Industri Padang. Pengambilan limbah aktivitas PETI dilakukan di Desa Bandar Alai Kari, Kecamatan Kuantan Tengah Kabupaten Kuantan Singingi Riau. Berikut Peta lokasi pengambilan sampel 


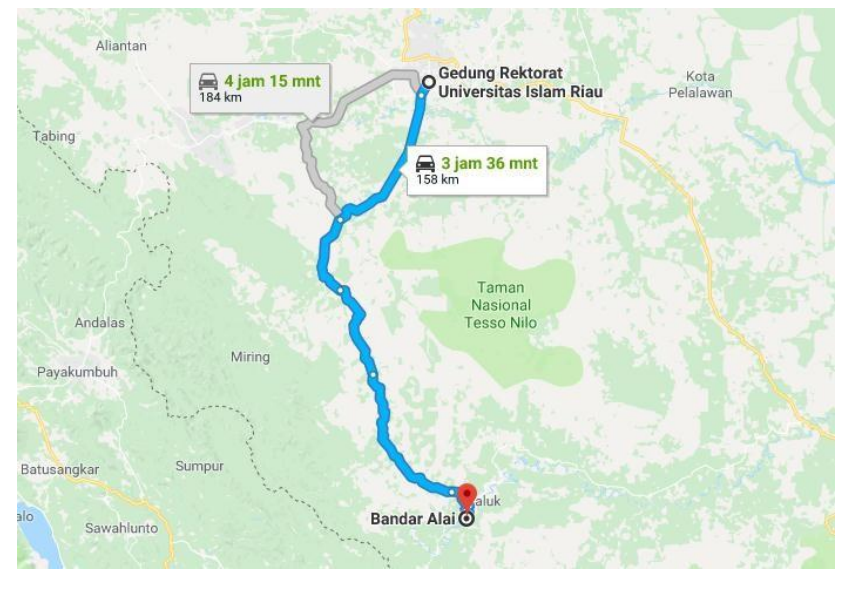

Gambar 1. Jarak lokasi pengambilan sampel dari Universitas Islam Riau ke Desa Bandar Alai Kari

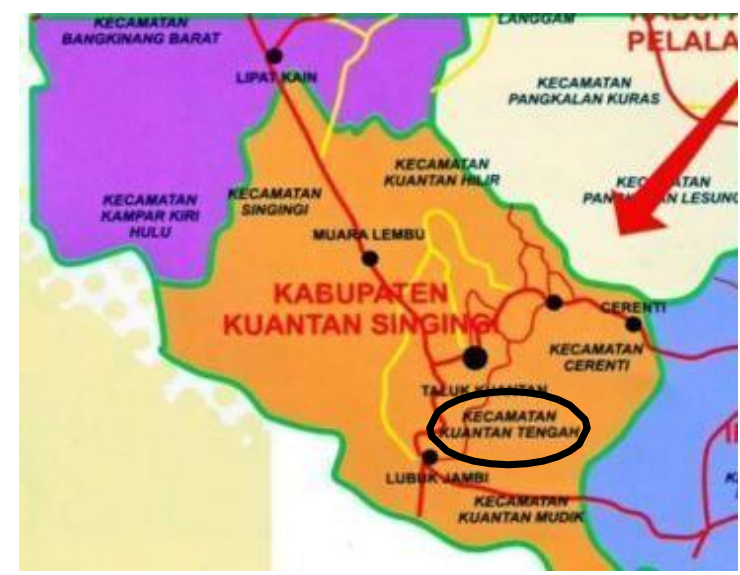

Gambar 2. Peta Kabupaten Kuantan Singingi

Metode yang digunakan dalam penelitian ini adalah metode survei. Penentukan titik sampling dilakukan menggunakan metode purposive sampling yaitu melihat dengan pertimbangan tertentu (dipilih 3 titik sampling dari lokasi hulu tengah dan hilir). Pengambilan sampel air sungai sendiri menggunakan metode random sampling. Setelah sampel diambil kemudian dibawa ke laboratorium untuk dianalisis. Sampel pada penelitian ini adalah sampel air Sungai Kuantan yang terdampak langsung oleh aktivitas PETI dan dilanjutkan dengan analisis di Laboratorium untuk mengukur kadar kandungan logam berat terakumulasi $(\mathrm{Hg})$ dan $\mathrm{pH}$. Penelitian yang dilakukan berdasarkan acuan SNI (Standar Nasional Indonesia). Metode analisis kualitas air sungai yang dilakukan seperti terlihat pada Tabel 1 berikut ini :

Tabel 1. Metode dan Acuan Standar Analisis Air

\begin{tabular}{l|c|c}
\hline \multicolumn{1}{c|}{ PARAMETER } & METODE & \multicolumn{1}{c}{ Acuan Standar } \\
\hline $\mathrm{pH}$ & $\mathrm{pH}$ meter & SNI 06.6989.11.2004 \\
\hline Logam Berat $(\mathrm{Hg})$ & AAS (Atomic Absorption & SNI 6989.78.2011 \\
& Spectroscopy) & \\
\hline
\end{tabular}

Sumber : Lab. Balai Riset dan Standarisasi Industri Padang

\section{a. Pengukuran kandungan logam berat ( $\mathrm{Hg}$ atau Merkuri)}

Pengujian kadar $\mathrm{Hg}$ menggunakan Standar Nasional Indonesia SNI 6989.78.2011. Metode pengujian air raksa $(\mathrm{Hg})$ dalam air dan air limbah secara SSA uap dingin atau Mercury analyzer sesuai SNI 6989.78: 2011 memiliki kisaran kadar $1 \mu \mathrm{g} \mathrm{Hg} / \mathrm{L}$ sampai dengan $20 \mu \mathrm{g} \mathrm{Hg} / \mathrm{L}$. Secara prinsip, ion $\mathrm{Hg}^{2+}$ direduksi oleh $\mathrm{Sn}^{2+}$ menjadi atom $\mathrm{Hg}$ dan selanjutnya atom tersebut dianalisis secara kuantitatif dengan spektrofotometer serapan atom-uap dingin pada panjang gelombang 253,7 nm. Pembuatan kurva kalibrasi pada rentang $1 \mu \mathrm{g} \mathrm{Hg} / \mathrm{L}-20 \mu \mathrm{g}$ $\mathrm{Hg} / \mathrm{L}$ dengan cara memasukkan $100 \mathrm{~mL}$ larutan standar kerja $\mathrm{Hg}$ pada kadar $(1,2$, 4, 8, 10, 15 dan 20) $\mu \mathrm{g} \mathrm{Hg} / \mathrm{L}$ ke dalam masing-masing Erlenmeyer $250 \mathrm{~mL}$. Kemudian tambahkan $5 \mathrm{~mL} \mathrm{H}_{2} \mathrm{SO}_{4}$ pekat dan 2,5 $\mathrm{mL} \mathrm{HNO}_{3}$ pekat kedalam masing-masing Erlenmeyer tersebut, lalu tambahkan $15 \mathrm{~mL}$ larutan $\mathrm{KMnO} 4$ dan tunggu sampai 15 menit. Bila warna ungu hilang tambahkan lagi $\mathrm{KMnO}_{4}$ sampai warna ungu tidak hilang. Setelah itu, tambahkan $8 \mathrm{~mL} \mathrm{~K}_{2} \mathrm{~S}_{2} \mathrm{O}_{8}$ dan panaskan 
dalam penangas air selama 2 jam pada suhu $95^{\circ} \mathrm{C}$, lalu dinginkan sampai suhu kamar. Jika suhu larutan telah dingin, maka tambahkan secukupnya larutan hidroksilamin $\mathrm{NaCl}$ untuk mereduksi kelebihan $\mathrm{KMnO}_{4}$ dan tambahkan $5 \mathrm{~mL}$ $\mathrm{SnCl}_{2}$. Ukur segera kadar $\mathrm{Hg}$ dalam larutan menggunakan SSA uap dingin yang sudah dioptimasikan sesuai petunjuk alat (Anwar Hadi, 2014)

b. Pengukuran $\mathrm{pH}$

Pengujian kadar pH menggunakan Standar Nasional Indonesia SNI 06.6986.11.2004. Tahapan pengujian berdasarkan SNI. Lakukan kalibrasi alat $\mathrm{pH}$ meter dengan larutan penyangga sesuai instruksi kerja alat setiap kali akan melakukan pengukuran. Keringkan dengan tissu selanjutnya bilas elektroda dengan air suling. Bilas elektroda dengan contoh uji. Celupkan elektroda ke dalam contoh uji sampai $\mathrm{pH}$ meter menunjukkan pembacaan yang tetap. Catat hasil pembacaan skala pada tampilan $\mathrm{pH}$ meter.

\section{HASIL DAN PEMBAHASAN}

Data-data berikut ini merupakan hasil analisis kualitas Air Sungai Kuantan terdampak Penambangan Emas Tanpa Izin (PETI) di Kabupaten Kuantan Singingi Riau.

\section{Derajat Keasaman (pH)}

Salah satu parameter kualitas air sungai yang diukur adalah nilai $\mathrm{pH}$. Nilai $\mathrm{pH}$ merupakan suatu indeks kadar ion hidrogen $\left(\mathrm{H}^{+}\right)$yang mencirikan keseimbangan asam dan basa. Nilai $\mathrm{pH}$ pada suatu perairan mempunyai pengaruh yang besar terhadap organisme perairan sehingga seringkali dijadikan petunjuk untuk menyatakan baik buruknya suatu perairan (Odum, 1971), dimana masingmasing organisme memiliki batas toleransi kadar minimum dan maksimum $\mathrm{pH}$, selain itu kecepatan reaksi serta tipe reaksi dalam perairan juga dapat dipengaruhi oleh kadar $\mathrm{pH}$. Pada tabel 2 dapat dilihat hasil pengukuran nilai $\mathrm{pH}$ aliran sungai Kuantan di desa Bandar Alai Kari.

Tabel 2. Derajat Keasaman $(\mathrm{pH})$

\begin{tabular}{|c|c|c|c|c|}
\hline \multicolumn{2}{|c|}{ No } & Lokasi & pH Air Sungai Kuantan & Standar Baku Mutu Air \\
\hline 1 & \multirow{2}{*}{ Titik 1} & (a) & 6,46 & $6-9$ \\
\hline 2 & & (b) & 6,47 & $6-9$ \\
\hline 3 & \multirow{2}{*}{ Titik 2} & (a) & 6,48 & $6-9$ \\
\hline 4 & & (b) & 6,49 & $6-9$ \\
\hline 5 & \multirow{2}{*}{ Titik 3} & (a) & 6,50 & $6-9$ \\
\hline 6 & & (b) & 6,49 & $6-9$ \\
\hline
\end{tabular}

Standar Baku Mutu : PP No.82 Th 2001

Berdasarkan Tabel 2 nilai $\mathrm{pH}$ di lokasi penelitian diantaranya berkisar diatas pH 6 antara 6,46 - 6,50. Hasil penelitian memperlihatkan adanya perbedaan $\mathrm{pH}$ pada tiap lokasi pengambilan sampel, tetapi secara keseluruhan nilai rata-rata $\mathrm{pH}$ di perairan tersebut masih tergolong baik karena berdasarkan angka baku mutu PP No.82 Tahun $2001 \mathrm{pH}$ perairan berkisar antara 6-9. Nilai pH dibawah 6 tergolong $\mathrm{pH}$ rendah yang mengindikasikan bahwa perairan asam, sedangkan $\mathrm{pH}$ diatas 9 
tergolong $\mathrm{pH}$ tinggi yang mengindikasikan perairan basa. Kedua kondisi ini tidak baik untuk kehidupan biota air,dan nilai $\mathrm{pH}$ kebanyakan perairan alami berkisar antara $\mathrm{pH}$ 6-9.

\section{Perbandingan Derajat Keasaman (pH)}

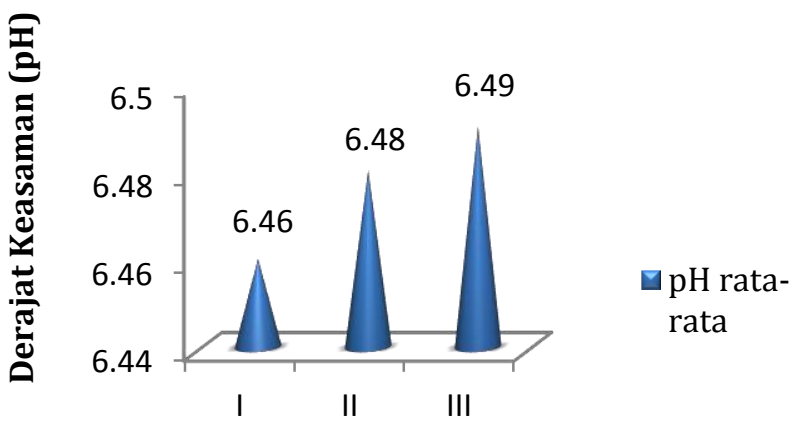

Lokasi

Gambar 3. Nilai pH rata-rata air Sungai Kuantan Desa Bandar Alai Kari

Dari Gambar 3 dapat dilihat bahwa terdapat perbedaan $\mathrm{pH}$ di tiap lokasi sampling, perbedaan tersebut dapat disebabkan beberapa hal diantaranya kondisi gas-gas dalam air seperti $\mathrm{CO}_{2}$, konsentrasi garam-garam karbonat dan bikarbonat, proses dekomposisi bahan organik di dasar perairan (Barus, 2004). Nilai pH paling rendah terdapat pada lokasi I dan $\mathrm{pH}$ tertinggi berada pada lokasi III, rendahnya $\mathrm{pH}$ di lokasi I disebabkan jaraknya yang sangat dekat dengan lokasi penambangan emas, sehingga diperkirakan mengandung pencemar lebih tinggi dibandingkan dengan lokasi II dan III yang posisinya lebih jauh dari aktivitas penambangan emas. Hal ini sesuai dengan pendapat (Safitri dan Putri, 2013) Banyaknya buangan yang berasal dari rumah tangga, industri-industri kimia, dan bahan bakar fosil ke dalam suatu perairan dapat mempengaruhi nilai $\mathrm{pH}$ di dalamnya dan sesuai dengan yang diungkapkan Mahida (1981) yang menyatakan bahwa perubahan nilai $\mathrm{pH}$ dapat dipengaruhi oleh buangan industri dan rumah tangga. Akibat buangan yang dikeluarkan oleh industri dapat menyebabkan menurunnya nilai $\mathrm{pH}$ yang akan berakibat fatal terhadap organisme perairan. Namun pada penelitian ini dapat dilihat bahwa nilai $\mathrm{pH}$ yang didapatkan masih memenuhi angka baku mutu yang ditetapkan meskipun masih tergolong kategori asam disebabkan adanya aktivitas industri seperti penambangan emas, namun terlihat masih adanya keseimbangan antara proses fotosintesis dan respirasi di perairan tersebut.

\section{Kadar Merkuri (Hg)}

Parameter pencemaran air yang sangat penting yang telah dianalisis pada penelitian ini adalah kandungan logam beratnya karena diketahui bahwa logam berat mempunyai sifat toksik dan berbahaya bagi kehidupan, hal ini sesuai dengan pendapat (Nuraini 2015) yang menyatakan logam berat menimbulkan efek 
kesehatan bagi manusia dan daya racun yang dimiliki akan bekerja sebagai penghalang kerja enzim sehingga proses metabolisme terputus. Pada penelitian ini logam berat yang dianalisis adalah kadar merkuri atau $\mathrm{Hg}$ dikarenakan beberapa hal diantaranya berdasarkan sifat kimia dan fisik tingkatan tertinggi daya racun logam berat terhadap biota air secara berurutan adalah $\mathrm{Hg}$ (merkuri), Kadmium (Cd), Seng (Zn), Timbal (Pb), dan Nikel (Ni) ( Narasiang, 2015), dan menurut (Stancheva, 2013) Merkuri merupakan salah satu unsur yang paling beracun diantara logam berat yang ada dan apabila terpapar pada konsentrasi yang tinggi akan mengakibatkan kerusakan otak permanen dan kerusakan ginjal. Selain itu kadar merkuri perlu diuji karena diketahui bahwa operasional penambangan emas biasa menggunakan raksa sebagai media pengikat emas dan membuang limbah yang masih mengandung merkuri ke perairan. Hal ini sesuai dengan pendapat (Mirdat, 2013) bahwa salah satu cara pengolahan bijih emas adalah proses amalgamasi yang menggunakan merkuri $(\mathrm{Hg})$ dalam proses pengolahannya. Selain itu menurut ( Buyang, 2013) logam berat merkuri dapat masuk ke perairan dalam bentuk limbah pertambangan yang digunakan untuk memisahkan emas dari batuan dan tanah dalam bentuk sulfida. Pada tabel 3 dapat dilihat hasil pengukuran Kadar Merkuri (Hg) aliran sungai Kuantan di desa Bandar Alai Kari.

Tabel 3. Kadar Merkuri (Hg)

\begin{tabular}{|c|c|c|c|c|}
\hline No & \multicolumn{2}{|c|}{ Lokasi } & Kadar Hg air sungai & Standar Baku Mutu Air \\
\hline 1 & \multirow{2}{*}{ Titik 1} & (a) & 13,00 & \multirow{6}{*}{$1 \mu \mathrm{g} / \mathrm{L}(\mathrm{ppb})$} \\
\hline 2 & & (b) & 13,6 & \\
\hline 3 & \multirow{2}{*}{ Titik 2} & (a) & 1,57 & \\
\hline 4 & & (b) & 1,61 & \\
\hline 5 & \multirow{2}{*}{ Titik 3} & (a) & 2,59 & \\
\hline 6 & & (b) & 2,67 & \\
\hline
\end{tabular}

Standar Baku Mutu : PP No.82 Th 2001

Berdasarkan hasil penelitian yang telah dilakukan dapat dilihat pada Tabel 3 masing-masing kandungan logam merkuri. Kadar merkuri mencapai 13,6 ppb atau 0,0136 ppm. Berdasarkan baku mutu PP No. 82 Tahun 2001 batas kadar merkuri adalah $1 \mathrm{ppb}$ atau $0,001 \mathrm{ppm}$, sehingga kadar yang didapatkan tersebut mencapai sudah jauh melebihi ambang batas baku mutu. Kandungan merkuri berbeda pada setiap lokasi penelitian. Adanya perbedaan kadar logam merkuri antara lokasi 1,2 dan 3 salah satunya dapat disebabkan $\mathrm{pH}$ dimana diketahui bahwa $\mathrm{pH}$ juga mempengaruhi kelarutan logam dalam air. Kenaikan $\mathrm{pH}$ air akan menurunkan kelarutan logam dalam air, sementara penurunan $\mathrm{pH}$ air akan meningkatkan kelarutan logam dalam air. Sesuai dengan data penelitian yang didapatkan dimana pada lokasi 1 dengan nilai $\mathrm{pH}$ terendah 6,46 didapatkan kadar logam berat merkuri (Hg) rata-rata sampai dengan 13 ppb, sementara pada lokasi 2 dan lokasi 3 dengan $\mathrm{pH}$ yang sedikit lebih tinggi yaitu, 6,50 didapatkan kadar logam berat merkuri 1-2 pp. 


\section{Perbandingan Kadar Merkuri (Hg)}

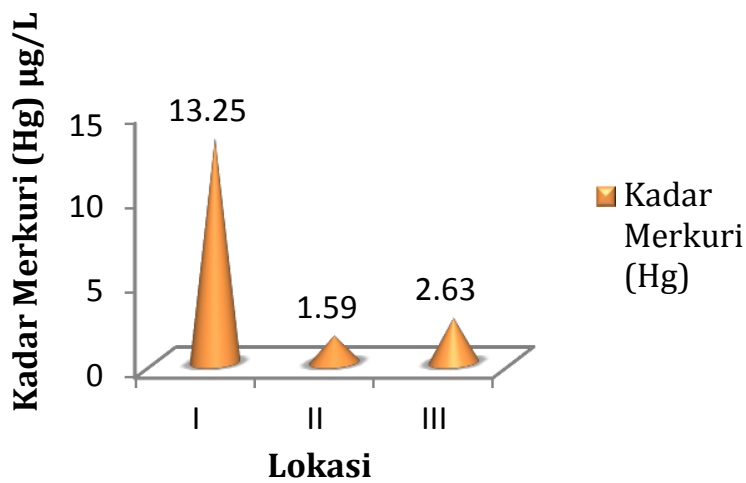

Gambar 4. Kadar Merkuri (Hg) rata-rata air Sungai Kuantan Desa Bandar Alai Kari

Berdasarkan Gambar 4 dapat kita lihat kandungan merkuri tertinggi berada pada lokasi 1 dengan rata-rata 13,25 ppb. Hal ini dikarenakan lokasi 1 sangat dekat dengan lokasi aktivitas penambangan emas sehingga diperkirakan limbah merkuri dari pengolahan bijih emas langsung dibuang di sekitar lokasi. Untuk lokasi 2 dan lokasi 3 kadar merkuri berkisar antara 1,5 -2,6 ppb, nilai tersebut walaupun lebih kecil dari lokasi 1 tetapi tetap masuk ke dalam kategori melebihi baku mutu karena baku mutu yang diizinkan hanya pada kadar 1 ppb, hal ini menunjukan bahwa masih banyak nya aktivitas PETI yang dilakukan sehingga sepanjang aliran sungai kuantan khususnya di desa Bandar Alai Kari terkontaminasi logam merkuri. Selain akibat limbah langsung penambangan emas, adanya merkuri di perairan tersebut dapat bersumber dari pelepasan senyawa merkuri sebagai efek dari aktivitas bakteri yang hidup pada perairan yang telah tercemar oleh logam merkuri, dimana proses ini berawal dari perombakan logam merkuri yang mengendap pada dasar sedimen perairan yang telah tercemar sebelumnya, selanjutnya ion-ion yang telah dirombak oleh aktivitas bakteri sangat mudah menguap dan sangat beracun bagi biota di perairan (Moore,1983 dalam Suhaemi, 2003).

Dari penelitian yang telah dilakukan dapat dilihat walapun masih adanya aktivitas PETI di sekitar lokasi tersebut tetapi kadar merkuri di perairan yang terdeteksi berkisar dari 1,5 hingga 13 ppb, diperkirakan tidak semua kandungan logam merkuri yang terdeteksi di perairan, karena merkuri sangat mudah terakumulasi dan mengendap. Hal ini sesuai dengan yang diungkapkan beberapa penelitian sebelumnya diantaranya (Harahap ,1991) logam berat merkuri mudah larut dan mengubah kestabilan dari bentuk karbonat menjadi hidroksida yang membentuk ikatan partikel pada perairan,kemudian mengendap membentuk lumpur. Penyebab logam berat merkuri tidak mudah terdeteksi di permukaan perairan karena merkuri memiliki sifat yang mudah mengikat bahan organik dan mengendap di dasar perairan sehingga kemungkinan akan lebih besar kandungan di dalam sedimen. Hal ini juga sejalan dengan pendapat (Rochyatun, 2006) yang mengungkapkan bahwa kadar logam berat dalam sedimen lebih tinggi dibandingkan dalam air karena terakumulasi dari pengendapan dan logam berat di dalam air lebih kecil karena proses pengenceran dan pengaruh pola arus. 


\section{KESIMPULAN DAN SARAN}

Dari hasil penelitian yang telah dilakukan, dapat disimpulkan beberapa hal sebagai berikut : Nilai Derajat Keasaman $(\mathrm{pH})$ masih dalam ambang batas angka baku mutu yang ditetapkan oleh PP No 82 Tahun 2001, dimana rata-rata $\mathrm{pH}$ di setiap lokasi penelitian diatas pH 6 . Sementara untuk kadar logam merkuri $(\mathrm{Hg})$ sudah melampaui angka baku mutu yang ditetapkan PP No. 82 Tahun 2001, dimana $\mathrm{Hg}$ pada lokasi penelitian mencapai $13 \mathrm{ppb}$ sementara batas baku mutu adalah $1 \mathrm{ppb}$. Berdasarkan kesimpulan yang didapatkan, dapat disarankan perlu dilakukan peraturan khusus bagi kegiatan penambangan emas tanpa izin mengingat tingginya kandungan logam merkuri yang sangat berbahaya dan beracun dan penyuluhan dampak sungai yang terindikasi kategori tercemar, selain itu perlu dikembangkan analisis untuk menanggulangi limbah sehingga kadar perairan tersebut dapat pulih ke kondisi semula.

\section{UCAPAN TERIMA KASIH}

Terima Kasih kepada Lembaga Penelitian Universitas Islam Riau yang telah membiayai penelitian ini sesuai dengan Kontrak Penelitian Nomor: 315/KONTRAK/LP-UIR/9-2017 dan semua pihak yang terlibat dalam penelitian ini.

\section{DAFTAR RUJUKAN}

Anwar Hadi, Asiah Asiah. 2015. Penentuan Batas Linearitas Metode Pengujian Air Raksa Dalam Air Secara Spektrofotometri Serapan Atom Uap Dingin Sesuai SNI 6989.78 : 2011. Jurnal Ecolab, Vol 9, No 1 (2015).

\section{Barus, T.A.2004. Pengantar Limnologi Studi Tentang Ekosistem Sungai dan} Danau. Fakultas MIPA. USU, Medan.

Buyang, Yorinda. 2013. Analisis Kadar Kadmium dan Timbal Pada Air di Lima Lokasi Sungai Totok Sulawesi Utara. Jurnal Agricola Tahun III No.1 Maret 2013.

Edward. 2008. Pengamatan Kadar Merkuri di Perairan Teluk Kao (Halmahera) dan Perairan Anggai (Pulau Obi) Maluku Utara, Makara Sains,Volume 12 No.2 97-101.

Mirdat, Patadungan,Y.S. 2013. Status Logam BeraT Merkuri (Hg) dalam Tanah Pada Kawasan Pengolahan Tambang Emas di Kelurahan Poboya, Kota Palu, e-J Agrotekbis 1(2): 127-134 ISSN 2338-3011.

Mahida, U.N. 1981. Pencemaran Air dan Pemanfaatan Limbah Industri. CV. Rajawali : Jakarta. 543p

Narasiang,A.A., Lasut, M.T., Kawung, N.J. 2015. Akumulasi Merkuri (Hg) Pada Ikan di Teluk Manado. Jurnal Pesisir dan Laut TropisVolume 1 No.1.

Nuraini, Iqbal, Sabhan. 2015. Analisis Logam Berat dalam Air Minum Isi Ulang dengan Menggunakan AAS. Jurnal Gravitasi Vol 14.No.1 Jan-Jun 2015. 
Odum, E.P. 1971. Fundamental of Ecology. W.B. Saunder Com. Philadelphia $125 \mathrm{pp}$.

Rochyatun,E., Kaisupy,M. Taufik dan Rozak, Abdul. 2006. Distribusi Logam Berat Dalam Air Dan Sedimen Di Perairan Muara Sungai Cisadane. MAKARA, SAINS, VOL. 10, NO. 1, APRIL 2006: 35-40

Stancheva,M., Makedonski,L., Petrova, E., 2013. Determination of Heavy Metals $(\mathrm{Pb}, \mathrm{Cd}$, As and $\mathrm{Hg}$ ) In Black Sea Grey Mullet. Bulgarian Journal of Agricultural Science. 2013, 30-34.

Safitri, M dan M.R. Putri. 2013. Kondisi Keasaman (pH) Laut Indonesia. Jurnal Fakultas Ilmu Dan Teknologi Kebumian. ITB. Bandung.

Tasriani dan T. Zulhadi. 2013. Pengendalian Pencemaran Sumber Daya Air Sungai Kuantan dan Sungai Singingi dengan Pendekatan Kearifan Lokal (Local Wisdom) di Kabupaten Kuantan Singingi. E-journal.uin-suska.ac.id. 